\title{
FROM POETICS TO METAPOETICS: ARCHITECTURE TOWARDS ARCHITECTURE
}

\author{
Lino Bianco \\ Faculty for the Built Environment, University of Malta, Malta \\ Faculty of Architecture, University of Architecture, Civil Engineering and Geodesy, Sofia, Bulgaria \\ e-mail: lino.bianco@um.edu.mt
}

\begin{abstract}
:
An undiscovered chapter in the history of architecture comes from the ex-Soviet Republic of Georgia. Poetics of Architecture is the name given to the studioworkshop at the Georgian Technical University set up by the Georgian architect Shota Bostanashvili (1948-2013). From 1990 until his death he delivered insightful, playful and rather provocative lectures on architecture at this university. He preferred to call his architectural philosophy, critical discourse on architecture. Themes ranged from poetics to metapoetics of architecture. His philosophy of architecture is illustrated by some of his designs and executed projects which demonstrate a drift from existentialism to the philosophy of play. This study includes reference to his last building, a project whose demolition Bostanashvili witnessed before passing away. Based on the concept of the return of the sacred, this edifice was a sort of counter movement to technogenic architecture.
\end{abstract}

Key words: architectural design, poetics, metapoetics, architectural discourse, technogenic architecture, Bostanashvili.

\section{Introduction}

The seminal publication by Anthony Antoniades on the poetics of architecture as a theory of design was published in 1990, a year prior to the end of Soviet era architecture. Independently of this publication, the manifesto for a poetics of architecture was launched by the Georgian academic and poet Shota Bostanashvili (1948-2013). This was the foundation of the studio-workshop Poetics of Architecture which he had set up at the Institute of Archi- tecture which institute was the precursor of the Faculty of Architecture, Urbanism and Design of the Georgian Technical University. This studioworkshop initiated metacultural discourse in architecture. The sub-title of this article is inspired by the name of an exhibition of his works with students which exhibition laid out the vocational role of the studio-workshop: "The main task of the studio is to awaken the abilities that lie dormant inside a child. To feel the joy and excitement of seeing things for the first time. This is the only path and this requires ... spiritual "exercise"" (Bostanashvili 2001). This exhibition was hosted by the Rustaveli Society in Tbilisi in November 2001.

Bostanashvili was an architect by profession, shifting to academia in the latter part of a career which ended with his sudden death during his lecture at a conference marking the demise of his friend, the poet and author Otar Chiladze. His professional career can be divided into two phases: Soviet and post-Soviet Georgia (Bianco 2017). The former is influenced by his association with the Design Bureau of Georgian Polytechnic Institute. During this period he collaborated with Vakhtang Davitaia, a leading contemporary architect of Georgia of international repute who dominated architectural design in his native country for the past half a century. This phase is mainly characterized by memorials, the most notable being the following:

- The Cube of Memory (Figure 1) in Senaki (1975), designed together with Davitaia, Bostanashvili's teacher Giuli Gegelia, and 
Vazha Melikishvili, recalls the youth who never returned from the Second World War;

- The Temple of Memory (Figure 2) in Mukhrani (1975), also designed with Davitaia (Kalandadze 2015, 318-327), was dedicated to the Georgian soldiers who lost their lives in the Second World War; and

- The Glory to Work (Figure 3) in Kutaisi (1979), another project with Davitaia, in honor of the over-achieving members of the public from the city.

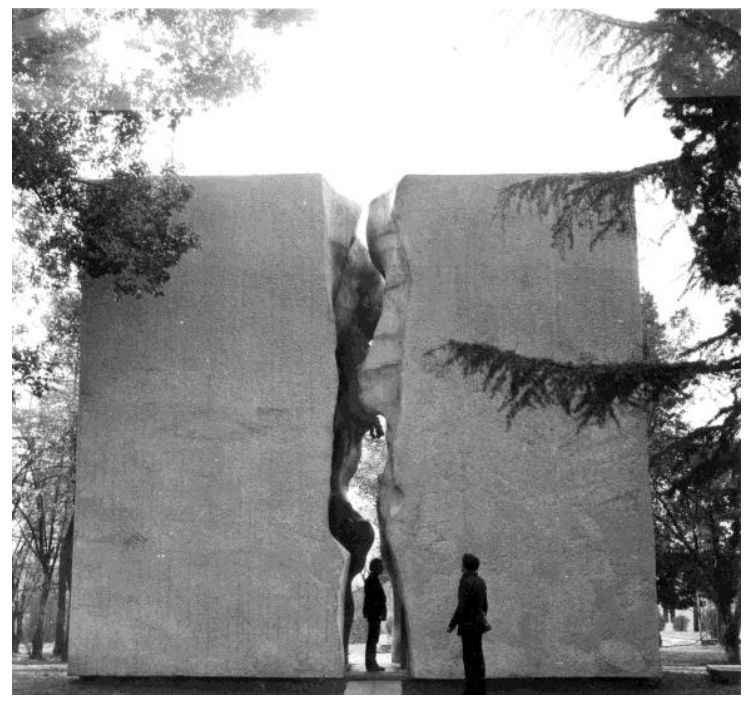

Figure 1: The Cube of Memory, Senaki, 1975 (Photo: (C) Shota Bostanashvili Archive, Tbilisi).

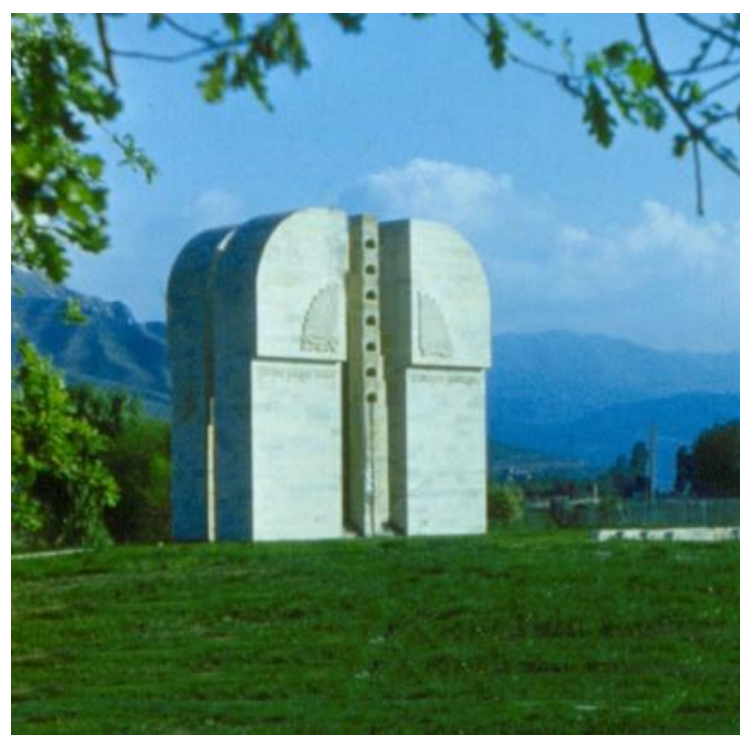

Figure 2: The Temple of Memory, Makhrani, 1975 (Photo: (C) Shota Bostanashvili Archive, Tbilisi).

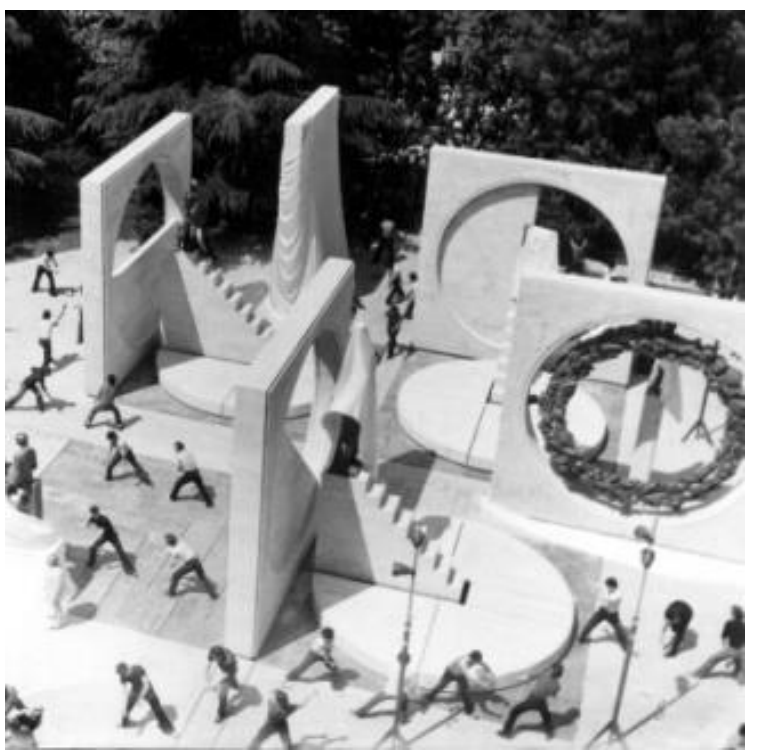

Figure 3: Glory to Work Memorial, Kutaisi, 1979 (Photo: C) Shota Bostanashvili Archive, Tbilisi).

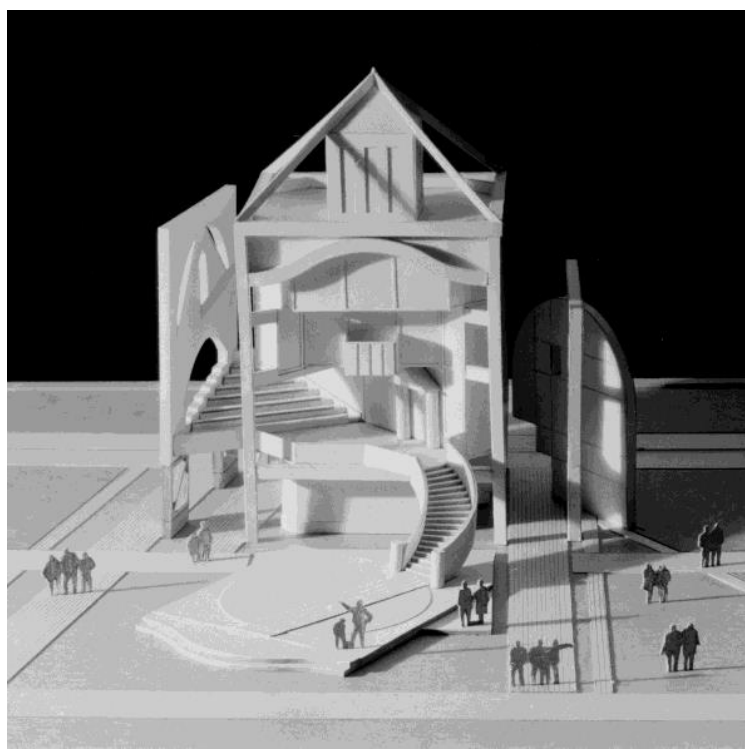

Figure 4: Model of the Actor's House, Senaki, 1985. (Photo: (C) Shota Bostanashvili Archive, Tbilisi).

Another architectural work-which was never executed - is the 1985 house-museum to commemorate the Georgian actor Akaki Khorava (Figure 4). The executed buildings which belong to the post-Soviet phase, both in Tbilisi, are a residence in the Vake district (Figure 5) and the Palace of Poetry (Figure 
6), the latter being his magnum opus. An unrealized project is the winning competition entry for the extension of the Rustaveli Metro Station in 2006, also in Tbilisi, submitted together with his son David (Figure 7). Through reference to these works, this article outlines Bostanashvili's shift from existentialism to the philosophy of play. It puts forward an exposition of his poetics of design and discourse on 'constructum,' and the evolution of metapoetics from the poetics of architecture. ${ }^{1}$

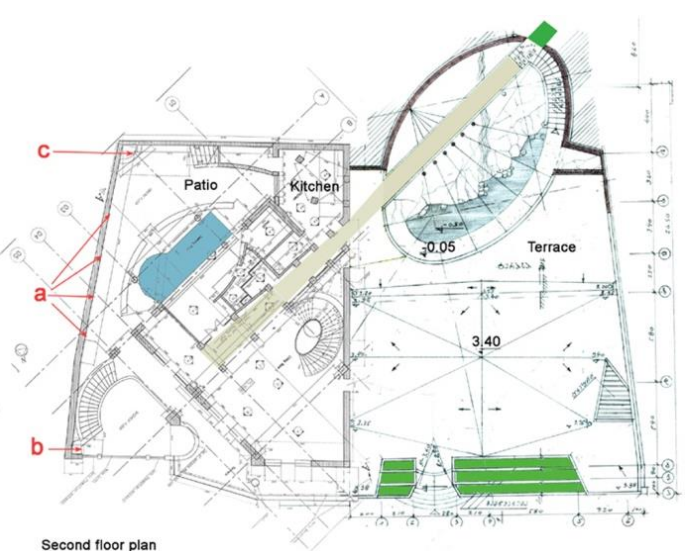

Figure 5: A private residence, Vake district, Tbilisi (1994-2001). (Photo: (C) Shota Bostanashvili Archive, Tbilisi).
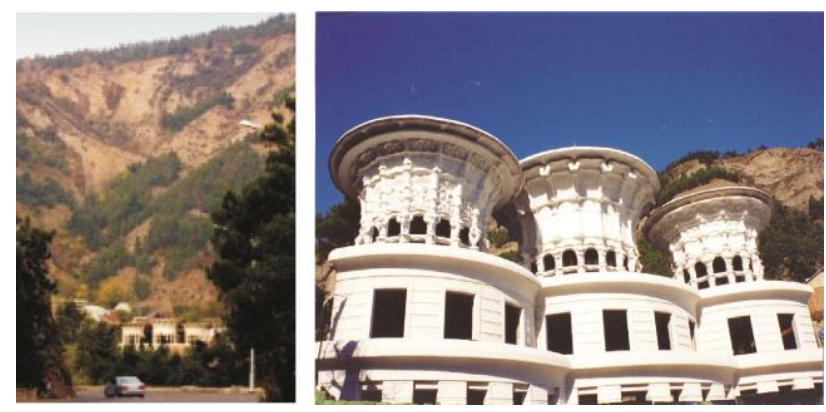

Figure 6: The Palace of Poetry, Tbilisi (1999-2003):

(Left) The site context and (Right): Detail of the towers.

(Photos: (C) Shota Bostanashvili Archive, Tbilisi).

\footnotetext{
${ }^{1}$ Constructum is a Latin word derived from the verb constructo which signifies something built. Since the Bostanashvilis attach a certain conceptual meaning to this word, they chose to introduce this Latin term for the English translation instead of writing it down as the verbal noun 'the Built'.
}
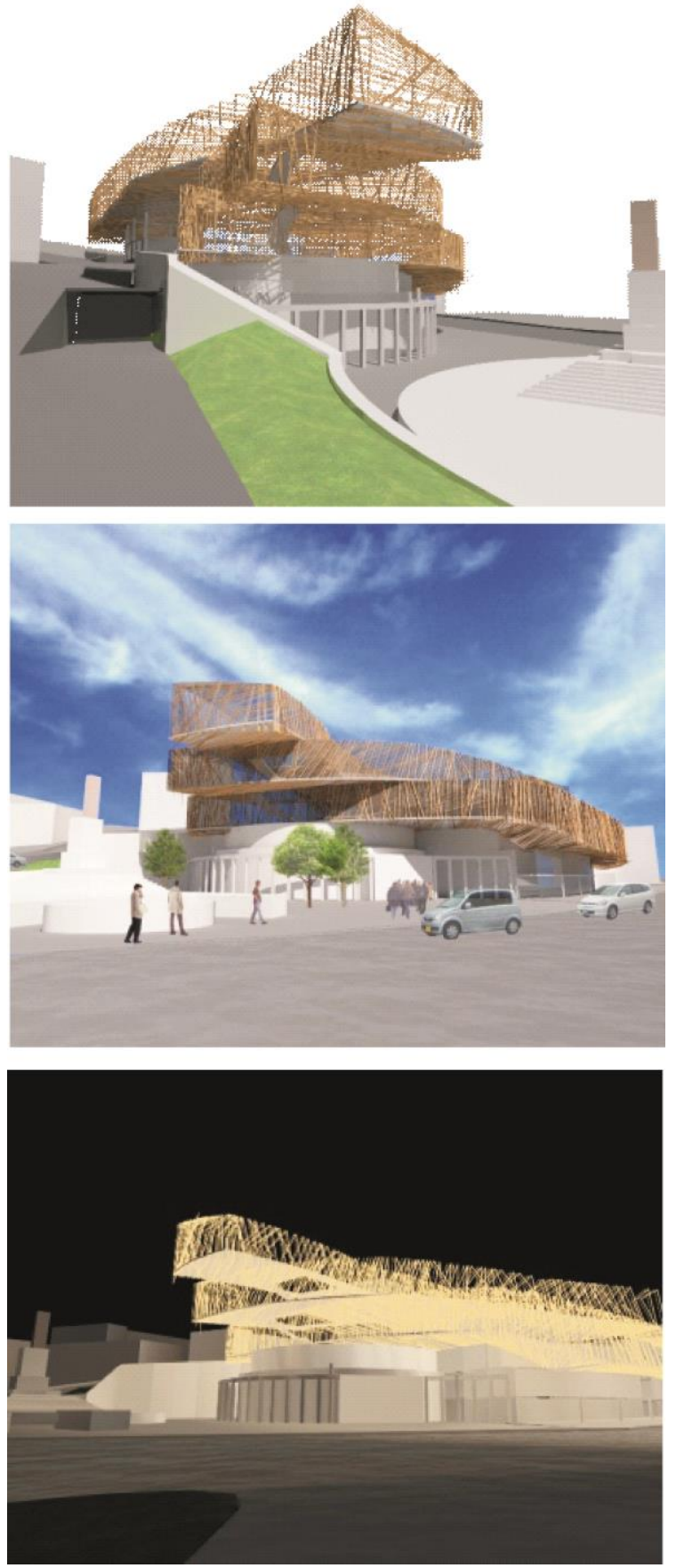

Figure 7: The competition winning entry for the expansion of the rooftop of Rustaveli Metro Station, Tbilisi, 2006. (Images: (C) Shota Bostanashvili Archive, Tbilisi).

\section{Existentialism and the Philosophy of Play}

The Cube of Memory was Bostanashvili's first leap into the architectural scene of Georgia. This project goes beyond the dominant Soc-Realism of 
the time. ${ }^{2}$ The cube represents the tragedy brought upon human lives, not only through the disruption generated by war but also through one's existential isolation (Bostanashvili 2013). The scarred cube is a kind of self-portrait: a seemingly stable individual hiding a tormented inner reality - an existential wound. Bostanashvili experienced the world as it was described by existential philosophy, the concept of "being thrown" (geworfen) into the world as described by Heidegger (1996). This sentiment of "estrangement" from the world, as Camus (1988) would have put it, was acutely significant for the young Bostanashvili. This may account for the reason why, in later years, the concept of play and world-as-stage became so important for him: the element of play overcomes existential pessimism.

The memorial Glory to Work is a statement of the intrinsic relationship between the lasting and the transient (Svetlov 1981): the frame, the stairs, and the pillar are themes which create and mark a place, and, the scene with changing participants, sculptures, and citizens renders the memorial an open art gallery, a theatre for art, the beacon of the cultural life of Kutaisi.

Play and culture are thus essential themes in Bostanashvili's poetics of architecture. As Huizinga ([1944] 1949) emphasized, culture developed from play: play was prior to culture, so the stage precedes architecture. The notion of the "enclosed arena" implies that it belongs to the realm of play. Ritual assumes that the stage is set. Architecture can provide a stage to plays, whether they are political, communal, or personal. In providing this stage, architecture gets engaged in play:

\footnotetext{
${ }^{2}$ Soc-Realism is short for socialist realism, the artistic style imposed by the Soviet Union from the early 1930s to the late 1980s and, post Second World War, on other socialist governments falling under the sphere of influence of the USSR. As a term it first appeared in Literaturnaya Gazeta, the official cultural and political newspaper of the Union of Soviet Writers, of 23 May 1932. Soc-Realism is a utopian realistic art which depicted life through socialist ideals. It is grounded in the proletariat revolution and "active socialist humanism" (Markov and Timofeev 1976, 245). The roots of this style dates to the first years post the Russian Revolution and by the early 1920s it emerged as the main approved official artistic style in Stalin's era. Its decline commenced in the late 1960s during the early years of Leonid Brezhnev's until its eventual end with the dissolution of the Soviet Union in 1991. For phenomenological observations on the aesthetics of socialist realism vide Terras (1979).
}

It is this capacity of playing that gives rise to original work. Recent developments in Georgian architecture show that Western thought is an object of imitation, an example that one should follow, a model to be copied. Modern Georgian architects impose on themselves normative Western thought, but through play it is possible creatively and critically to react to different streams - Western ideals of architecture or the kitsch desires of local clients (Bianco 2016, 463).

The Temple of Memory is a deconstructed sign. The opening of the arch is solid; it prevents the triumphal route and instead halts the visitor. Thus, the deconstructive gesture, being that of a signifier, is a triumphal arch breaking away with its signified triumphal passage. This memorial, together with the Cube of Memory and the Glory to Work, departs from the traditional representational monuments typical of Brezhnev-era architecture. ${ }^{3}$ They demonstrate the tradition of remote monumentality as surmounted; they are a pretext to make architecture. Their architecture created an array of contexts:

This tradition created a distance between the viewer and architecture; it turned him [sic] into passive observer who had to interpret the work according to pre-established codes of signification. These memorials eliminate this distance; they make space and place for the visitor; they form a space for social interactions; they offer interactivity. They are open to a multitude of readings (Bostanashvili 2013, 60).

The Actor's House suggests a double reading. It is a house for an actor and a house that actsit is a house that plays. The elevations of the house act like masks, and the masks represent architectural elements: stairs, openings, and recognizable silhouettes. The four masks that comprise the building are

\footnotetext{
${ }^{3}$ Brezhnev-era architecture is the Soviet socialist architectural style which emerged during the early years of Leonid Brezhnev (1964-1982) and endured under Yuri Andropov (1982-1984) and Konstantin Chernenko (1984-1985). It lasted with the dissolution of the U.S.S.R.. During this period the architects in the East reassessed modernism, rather than, as in the capitalist West, moved onto postmodernism (Chaubin 2011). Recent publications refer to Brezhnev-era architecture as socialist modernism.
} 
rotated slightly, being a bit displaced and never perpendicular. One "mask" (wall) lies on the floor, marking a small plaza in front of the building. Though all of the elements come from familiar architectural vocabulary, this play of rotations and shifts renders the familiar unfamiliar (Bostanashvili 2013, 60).

\section{Poetics and Discourse on Constructum}

Bostanashvili's work is marked by a vocational call for innovative paradigms for architecture, one where the frontiers between art and architecture, space and text, theory and practice are blurred. His proposition for a poetics of architecture is a movement from words to things and back. It knows its beginning in his architectural practice, shifted to paper architecture and peaked in pedagogical activity: "Poetics of Architecture fills the vacancies left on the place of philosophy and aesthetics, the vacancies where the configuration of knowledge is altered. In the condition of shifted epistemological field the Poetics of Architecture is a response to the problems of our pragmatic time and crisis of "ending" (Bostanashvili 2014).

A publication which presents his understanding of the notion of poetics of architecture is Butza: Architect Victor Jorbenadze (Bostanashvili and Bostanashvili 2012). It is a book of telling his story of Butza (Bianco 2016, 459), the nickname for Jorbenadze in the academic circles of Tbilisi. This work is a text on architecture and not just about the architect whom the publication recalls: "With this book we begin critical discourse of architecture-reading through differences and narrative, where critique takes the task of not just studying ideas, but their entropic production. We believe that critical discourse should include the impossibility of the discourse (narrative) itself and hindrances - a potential for demythologization" (Bostanashvili and Bostanashvili 2012, 4).

In the preamble to the manifesto for a poetics of architecture, written twenty years prior to the above cited statement, although not explicitly declared, Bostanashvili states that his effort is towards humanitarian thinking beyond the stereotypical. His focus is on metacultural reflections and on the praxis of critical reading of the history of architecture:

My effort is directed towards [the] return of the Poet and the Myth in architecture; this im- plies primacy of humanitarian thinking - return to nature and humanity; Respect towards heritage does not hinder recognizing the fact that Culture is a barrier, it creates stereotypes in thinking, that must be overcome; The 'gene' of architecture is irrational and is intended to govern the space through symbols; Architecture is art and defies methodological clichés (Bostanashvili 2010b).

One notes here two interpretations of the concept of myth: the first is understood in relation to poetry as the most fundamental creative force of culture; the second is linked with semiotic interpretations of myth. In his study of symbols and the linguistic messages of architecture, Bostanasvhili draws on Barthes (1972) and Eco (1968). For Barthes, "the function of myth lies in deforming and not in mystifying" (Barthes 1991, 20) whilst for Eco, contemporary opinion "no longer recognizes the discipline that myths impose on the symbols they involve" (Eco 1994, 21). These messages involve coding which gives rise to reading and composing.

Myth in architecture is grounded in nature; place is its material support. It is in this context that one has to read Bostanashvili's definition of architecture in terms of emotion, or a beauty beyond empirical reality. It is beyond dogma; it is what reality lacks:

Architecture is art-an exceptional ability to express emotions and evoke them in others; Architecture is art-it means to retain childhood and passion for play; to retain faculty of bewilderment and exhilaration; bewilderment with all that surrounds you and with all that you see as if for the first time; exhilaration that being is marvel and vision is rejoicing; Architecture is art - it is a realm where one is not punished for transgressing dogmas and canon; where one is not punished for diktat, intrigue and provocations, since the Beauty is ascertained. The source of Beauty lies beyond empirical reality, it is devoid of utility and causes disinterested delight; Art is that what the reality lacks, that what it conceals; what if reality is innocent and does not conceal anything, and art is a crime that the reality bears; The 'Beginning' is depleted; it is obvious that we have to make again the 'Beginning' with 
the ingredients of the 'End' (Bostanashvili 2010b).

The same writings define architecture in terms of emotions; one reads that "in the era of metaculture and digital technologies, space is - above all-a text ...” (Bostanashvili, 2010b). Understanding architecture as text led Bostanashvili, together with his son (who was a doctoral student at the studio-workshop), to introduce a specific term in the Georgian language which linked both terms. The concepts of sign and built, in later works renamed as constructum, deal with the problems of semiotics of architecture by inscribing these concepts into the Georgian language.

This linguistic play is a conceptual part of the research: in Georgian, the word for sign is nishani, whilst the word for "what is built" is nasheniconstructum in Latin. "This deconstruction of one morpheme becomes the starting point into critical discourse on architecture" (Bianco 2017). Bostanashvili later makes use of the concept of nasheni to supplant architecture. Recalling Barthes (1979, 73 $81)$, nasheni is to architecture what text is to literature.

Bostanashvili is still far from the concept of nasheni-text. His major philosophical concepts relating to the poetics of architecture are outlined in one of his last publications, which is found in the Georgian academic journal Semiotics (Bostanashvili and Bostanashvili, 2008). The underlying logic of the argument runs as follows: architecture, being discourse on space and belonging to space, is at the same time a discourse of the interesting. The word interest is composed of two morphemes: inter and esse, implying a state of "being" in "between" (Bianco 2017). With this in mind, one leaps "to the notion of border; blurring borders becomes a practice of discourse - this practice is permitted in written Georgian language" (Bianco 2017, 56).

Now the concept of ruins (destructum) is first introduced, albeit still not developed. The sign of ruins is introduced as the state of pragmatism in contemporary architecture, the final problem being the cycle of deconstruction-reconstruction. To bring architecture into the realm of metaculture, two paths are proposed: metapoetics and semiotics:

The altered episteme of [the] new epoch puts forward text instead of oeuvre-Constructum instead of Arche and architecture. Constructum is a free play of signifiers. Constructum-textus (Latin-“textile," "net") suggests, that we are in the net. Constructum started the movement towards critical discourse of architecture (Bostanashvili 2010b).

By presenting the neologism nasheni, Bostanashvili hints at the specific nature of the semiotics of architecture (Bostanashvili and Bostanashvili, 2009). Nasheni represents something that is material-the built - though it is, at the same time, a language and a sign. It is both and none at the same time, something other, a signifier with two intangible signifiers.

The Temple of Memory evokes the form of a triumphal arch only to negate it immediately. "[Nasheni] confirms its being between presence and absence, 'inter / esse'; that it is 'interesting'; its simultaneous polysemantics/dissemination" (Bianco 2017, 57). In this context Bostanashvili makes reference to Plato's intractable concept of Khora in the Timaeus. This is the point of departure of Derrida's publication with Eisenman on the architectural project for the Parc de la Villette. For Derrida, "Chora belongs neither to Eidos, nor Mimesis", it is a "place without space, before space and time" (Derrida and Eisenman 1997, 91). Khôra is a "paralogical and metalogical superoscillation" (Derrida and Eisenman $1997,15)$ and oscillation, as McCaffery notes (2008, 251 ), between the double exclusion of neither-nor and the participational both-this-and-that. A key point is the tautology that whatever is interesting is so because it is interesting. And, the interesting is not related to the pragmatic or the aesthetic. Bostanashvili's idea was to split the word so that 'inter / esse' becomes "being in between," and being between gives rise to the interesting.

In presenting the concept of constructum (Bostanashvili and Bostanashvili 2009, 118), "it is the language itself that works; language about the language that already took hold of the built (history, theory and poetics of architecture)" (Bianco 2017, 57). This introduces metapoetics of architecture, "rewriting the history of architecture where stylistic and historical interpretations are supplanted by thematic reading (mass, wall, column, stair, frame, blob/surface/veil)" (Bianco 2017, 57). It is not only about the creation of language; it is also an example of such practice. While discussing semiotics of nasheni, two theoretical themes from Epstein are 
introduced: semionics as the science about the formation of new signs; and semiergon as the practice of sign production (Bostanashvili and Bostanashvili 2009, 122): "To think - means to re-create the language" (Epstein, 2004: 655). Nasheni is such recreation of the language of architecture.

As a free play of signifiers, nasheni implies absence of deep structure and advance of the surface, or in Bostanashvili's terms, the "veil." There is no hidden signified to be uncovered behind the veil. There are just surfaces beneath surfaces. The theme of "veil(ing)" became the central theme in Bostanashvili's late years. The veils mark the beginning of new architecture, Derrida would have argued: instead of solid sign/architecture, one is faced with a veil, a surface of signifiers pointing to each other, a text, nasheni. The discourse on veils was explored in Bostanashvili's obituary for Derrida, where he takes on Derrida with Derridian writing (Bostanashvili 2006). Ride in Georgian means "veil;" U-Ridod means "without veil," but also it means "without reverence." For him, the present urban chaos of Tbilisi is a case where buildings are built next to one another without "reverence" (Bianco 2017, 55-56). A design which illustrates his understanding of the notion of veiling is Rustaveli's Metro Station. His proposal makes use of:

... a language of dynamic, open, penetrable fluid shapes; a language of ordered chaos, of planned randomness. The skin of the three main bodies of the building follow the movement of the adjacent avenue and represents a kind of vestigial structure. The skin goes beyond being a decoration, becoming part of the architectural body (Bostanashvili and Bostanashvili, 2006).

This exposes the major paradigmatic shift in architecture which may be summarized as follows: architecture reveals itself as tectonics and order, as well as implying the ideological. The rigid tectonic is supplanted by "envelopes," "wrappings" meaning a kind of surface that does not communicate the signifiers, the programmatic and structural contents of a building. Poetics of architecture labels such a surface "veil." Veils lead to the free play of signifiers, and digital technologies of 3D design and manufacturing make veils possible.

\section{From Poetics to Metapoetics}

For Bostanashvili, the poetics of architecture is the philosophy and practice of architecture; it is an adventure of space in culture; it is a way of spatial synthesis. It was born "when eagerness to build was not synchronous with our cultural condition; when construction was replaced by destruction" (Bostanshvili 1995). The years from 1988 to 1993 were dominated by the Georgian civil war, as well as characterized by inter-ethnic and intra-national conflicts. Architectural practice was halted, but the endeavour to do architecture continued (Bostanashvili 2013, 61). To reinforce his opinion, he cites Woods' position: "resist the idea that architecture is a building; ... resist the idea that you need a client in order to make architecture" (Woods, n.d.). Whilst the country was in a process of total collapse, architectural students spent hours in a freezing auditorium listening to the poetic potential of architecture, a dialogue of cultures and a culture of dialogue. Where is space? Where does the space of culture begin? At this stage Bostanashvili refers to the Biblical text of the Genesis (1:6-7): “'And God said, 'Let there be a vault between the waters to separate water from water. ... So God made the vault and separated the water under the vault from the water above it. And it was so."

The basic concepts of below and above define space. The other translation of what is between, translated as vault, is a firmament. This word has the meaning of both space and solid. Firmness is a pivotal term in the Vitruvian triad defining architecture. A separator delineates the threshold between the in and out, as well as between below and above, the floor and the ceiling. These are the omnipresent paradigms of architecture, the foundations for texts on aesthetics and poetics of architecture. This leads to the foundations of the metapoetics of architecture:

Metapoetics of Architecture is a reflection on the said texts and at the same time a new practice of spatial synthesis; it is a response to the problems of our pragmatic time and crisis of 'ending' in conditions of shifted epistemological field; it started at the threshold of digital technologies (1990) and its experience spans over twenty years (Bostanashvili 2010b). 
Since we live in the era of metaculture rather than merely culture, he argued that it would be more correct to talk about metapoetics rather than poetics.

Bostanashvili claimed that culture had undergone a major paradigmatic shift. At this point he makes reference to the crisis of metaphysics which was exposed by Derrida. This crisis marks a break in culture, or as Foucault (1994) would put it, a change of epistêmê. This shift in the way knowledge is organized makes us consider culture in a different light - namely, we ought to talk of metaculture. Instead of philosophy, we have discourse. Moreover, in the case of architecture one could speak about critical discourse on constructum, or architecture as text.

The publication of Bostanashvili's "Image, House, Name" (2003) is useful to understand metapoetics and critical discourse on architecture, especially since the words image, house, and name sound similar in Georgian (sakhe, sakhli, and sakheli respectively). They not only represent Bostanashvili's way of thinking, but illustrate his specific technique of writing, one which bears a resemblance to Derrida. The objective of this publication was to put forward a case (for a state award) for the nomination of the Courthouse in the city of Poti, a building designed by Gegelia. ${ }^{4}$ Bostanashvili made use of the phonic and graphic similarity of these words to build a theory of architecture told through Georgian language (Bostanashvili 2003, 12). Bostanashvili argues that this building manages to become free from ideology (the court system) and perform like a piece of architectural art-work. Hence, the name (courthouse) never translates deliberately into an architectural image, which is to say that form and function have a conventional relationship: "The image is this transitory phenomenon that stands between words and things" (Bostanashvili 2001, 6:38. It disobeys the name; so, Architecture returns to the home of architecture proper. He concludes that, nowadays,

\footnotetext{
${ }^{4}$ Guili Gegelia (1942-) is a professor of architecture at the Georgian Technical University and a leading architectural expert and a former advisor to the Government of Georgia and to the Foundation for the Preservation of Cultural Heritage Sites of Georgia. He was involved in the restoration, reconstruction and the rehabilitation of the historic town of Sighnaghi, the ancient city of Mtskheta and the Black Sea coastal city Batumi.
}

when everyone is obsessed with "smart housing," it is difficult to make beautiful houses. ${ }^{5}$

The poetics of destructum (whatever is destroyed) becomes a major theme for Bostanashvili. This recalls Eco's publication On Beauty: A History of a Western Idea, which includes a chapter on the poetics of ruins (Eco 2004, 285-287). Bostanashvili himself makes reference to a multitude of seventeenth and eighteenth century artists - such as Lorrain (1600-1682); Rosa (1615-1673); Panini (16911765); Servandoni (1695-1766); Piranesi (17201778); and Robert (1733-1808) — who were charmed and obsessed by ruins. Reviewing the paradigm of destructum ("ruin") in culture, Bostanashvili starts with the ruin that Adam initiated in Paradise (Genesis 3:6). ${ }^{6}$ The paradigm is carried into Biblical myths: Noah's Ark and Babel (Gen. 6-9, 11:1-8); Moses destroying the stone tablets (Exodus 32:1819, Deuteronomy 9:16-17); the fall of Jericho (Joshua 6); and, Samson and the ruins of the temple of Jerusalem (Judges 16:23-31). Besides Biblical narrative, Bostanashvili discusses examples of ruins in the history of culture, concluding with his own story: his biography is constructed by different destructive events, starting with his family being torn apart by Stalinist repression and concluding with the obliteration of his architectural heritage, the 2013

\footnotetext{
${ }^{5}$ One may argue that conflation and the fallacy of false bifurcation is present in Bostanashvili's philosophy, where technology and beauty are diametrically opposed and thus irreconcilably. Bostanashvili argues against the idea that beauty is a result-for example, rational decisions, correct planning, and so on. Since the advent of modernism, the concept of beauty has been displaced and is nowadays simply a consequence. He puts forward the motion that beauty is the point of departure; without an initial act there can be no beauty. Beauty only comes from beauty; it is consumed when it is the prime and central mover of architecture. Function is an obsession; eco/green/sustainable architecture is an obsession; intelligent/smart/digitally controlled environments are an obsession. The effect of obsession is an unknown. Dr Frankenstein was obsessed with science; he hoped the result would be sublime but the tangible outcome was a monster. This does not imply that science produces monsters; it illustrates that obsession may result in unpredictable alienating effects. Obsession on technological aspects of architecture can produce alienating machine architecture. 6 The doctrine underlying the Christian myth of "The Fall" is essentially the interpretation of the Eden narrative in Chapter 3 of Genesis, the first book of the Old Testament (Jones 1966).
} 
demolition of the Palace of Poetry (Bostanashvili 2013).

Is Bostanashvili's metapoetics a "parapoetics," a leap to the architectural? McCaffery, in his paper "Parapoetics and the Architectural Leap" (2008), explored the linkages between language, architecture, and the human from Babel to Derrida. Bostanashvili's metapoetics of architecture and its practice is a response to the issues related to our pragmatic time. It bridges the gap between philosophy and aesthetics. It is at this stage that the pattern of knowledge undergoes transformation and becomes the study of the culture of architecture:

Metapoetics of Architecture fills the vacancies left on the place of philosophy and [a]esthetics, the vacancies where the configuration of knowledge is altered. In this regard Poetics could, as well, be called culturology of architecture. Metapoetics of Architecture introduced new apparatus ('inter esse' and conceptual triad: 'Image, House, Name') and concepts; among those the dichotomy of Constructum/Destructum is a binary pair, opposition that architecture never had. Destructum is not only a material destruction, but a mental one too (e.g. blocking off and eliminating the view in the city) (Bostanashvili 2010b).

\section{Concluding Comments: Pilgrims and XXI Century Civilization}

In "Seafaring Pilgrims," Bostanashvili provides a semiotic reflection on his design entry entitled The Pilgrims (Figure 8) (Bostanashvili 2010a, 335). His submission placed first in the architecture-culture category for conceptual designs; it was entitled "A space for XXI Century Civilisation" in a competition held in 1988 by the International Academy of Architecture. The sub-title of the entry reads "Travelling islands serve [as] asylums for those who suffer and are in doubt." The Pilgrims is an artificial wandering archipelago of five plus one islands which drifts to the need of humanity to bridge culture. "The Pilgrims is a sign-creative image, graphical and linguistic semiurgic text. It grew from the names/images of specific, local (Georgian) culture and transformed into global, general image/name/house. Private and general, having different signifiers and signifieds, are linked here through a sign (Bostanashvili 2010a, $335)$.

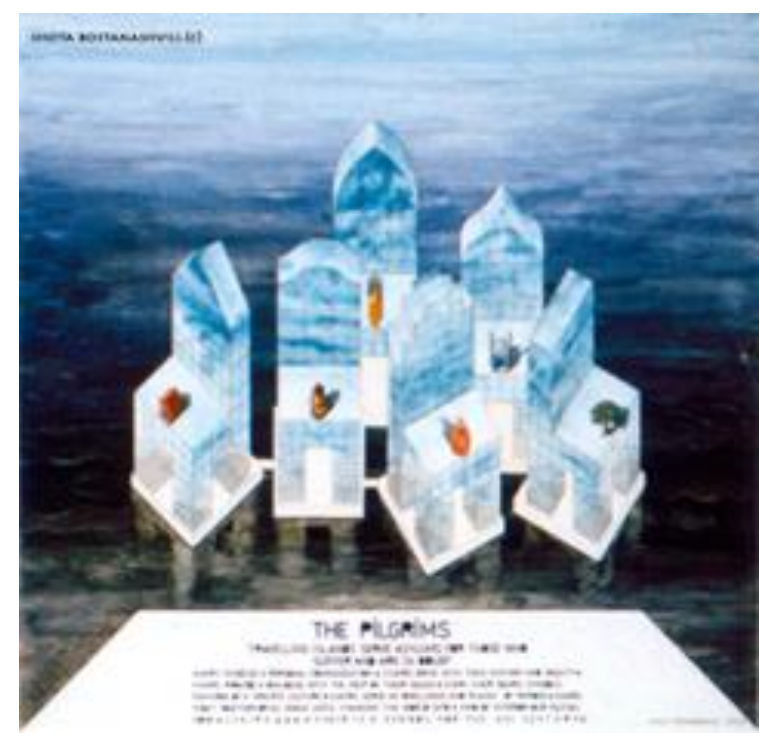

Figure 8. The Pilgrims is an artificial group of five plus one islands each consisting of a colossal glass chair. (Image: (C) Shota Bostanashvili Archive, Tbilisi).

The number five does not refer to the continents; they represent the five major world religions, with the sixth being nature. Thus, five temples of the major faiths sit on the chairs, one temple per chair, and a tree is placed on the sixth. The islands communicate, thus linked, while floating independently, through the back of the chairs which are made up of screens. The Pilgrims symbolize discourse and tranquility, a place for dialogue, a space for shattered humanity to lie at rest, "XXI century is a space for dialogue of cultures and the 'repose' of exhausted mankind" (Bostanashvili, 2010b). This publication reads his project through Barthes's essay "The Rhetoric of the Image" (Barthes 1977). In his semiotic analysis of the Panzani advert, Barthes uncovers a stratigraphy of meanings. He identified three classes of message: the linguistic (text), the symbolic (the connoted image) and the literal (the denoted image). Bostanashvili introduced in Barthes's analytical scheme his own signs: sea, sky, and temples on chairs instead of pasta, tomatoes, and other items. He had undertaken a (B) $\operatorname{art}(\mathrm{h})$ istic performance, a semiotic play of The Pilgrims on Barthes' stage.

Reflections on XXI century culture found another turn with Bostanashvili's last project. The 
Palace of Poetry emerged on the boundary of millennia, on the boundary of the city and nature, and on the boundary of Soviet and post-Soviet space (Figure 6). It is an essay in the dialogue of architecture and nature; it is a search and the return of the sacred. This project belongs to the mytho-poetical aspect of Bostanashvili's philosophy of architecture. Another executed project which was inspired by the same philosophy is a private residence in the same capital (Figure 5). This project became a stage for Bostanashvili to weave a mytho-poetic narrative on the home; however, construction on both sites was halted in 2004. They stood for nearly a decade, almost complete, but were erased by market forces following their acquisition by new owners who wanted to redevelop the sites into apartment blocks. After their demolition, he found refuge in poetryhis new "home."

Bostanashvili published Four Discourses in 2012, a cycle of four poems on the classical Greek conception of nature, that is the theory of matter as comprised of the four basic elements: water, fire, air, and earth. The elements are completely detached from any mythology, being understood as belonging to language. Bostanashvili works with the language in an architectural manner, and it is here the writing style in "Image, House, Name" (Bostanashvili 2003) is pushed to its limits. In his poetry, he made the Georgian language speak in an avant-garde manner (Bostanashvili, n.d.); it is a "semiotic revolution" in Georgian poetry (Lomidze 2012, 6).

The existential and the cultural are the main and timeless dimensions of architecture. Architecture is never created through technics but always through poetics. Architecture is born through the dialogue of an individual with the world: therein lies its existential dimension. The human spirit wants to mark the place of being; the human spirit asks for more space than the body requires. On the other hand, the individual is always already placed in culture. Therefore, no architecture can be born without the ability of the subject to comprehend, navigate, and expand the boundaries of the culture that creates her and she, in turn, recreates. This could be a summary of Bostanashvili's philosophy and that of his studioworkshop, where he did architecture together with his students on paper. This architecture was architecture in its own right and not merely a dream, if only it could be built. Furthermore, images produced in the studio-workshop lose their cultural value if built. They are fully significant on paper. The surface of paper becomes the proper place for architecture.

To some degree, Bostanashvili's poetry of later years was an example of architectonic writing-he arranged each letter and line so that the poetic text has an additional dimension, leaving the verses of the poems to appear as if they have been built. Here Bostanashvili found his own place in the realm of architecture: all the streams of existential thought, philosophy of play, and the semiotics of culture came together to create a unique architectural philosophy conveyed through the Georgian language.

\section{Acknowledgements}

The author would like to thank Professor David Bostanashvili for translating the Georgian texts and the anonymous reviewers for their valuable comments on an earlier version of this paper. The author expresses gratitude to the Shota Bostanashvili Archive for allowing him to reproduce the included Figures.

This research was financially supported by the Academic Work Resources Fund of the University of Malta.

\section{References}

Barthes R (1979) From Work to Text. In Textual Strategies: Perspectives in Poststructuralist Criticism, ed. Josue V. Harari, 73-81. Ithaca, New York: Cornell University Press, .

Barthes R (1972) Mythologies. Translated by Annette Lavers. London: Paladin.

Barthes R (1991) Mythologies. New York: The Noonday Press.

Barthes R (1977) The Rhetoric of the Image.In Image-Music-Text, ed. Roland Barthes, 32-51. Translated by Stephen Heath. London: William Collins Sons and Co.

Bianco L (2016) Butza: Architect Victor Jorbenadze. The Journal of Architecture 21.3: 459-464. doi: 10.1080/13602365.2016.1183384. 
Bianco L (2017) Shota Bostanashvili, Architectural Discourse and the Foundation of Poetics of Architecture in Georgia. Paper of BAS: Humanities and Social Sciences 3.1: 49-59.

Bostanashvili D (2013) Architect's Own time. Style 46: 60-63 (in Georgian).

Bostanashvili D (2014) Poetics of Architecture at Liste 2014. Basel: LISTE Art Fair. https://www.facebook.com/Poeticsofarchitecture/ph otos/a.747030328672399.1073741829.11120223225 $5215 / 747030432005722 /$ ?type $=3 \&$ size $=960 \% 2 C 720$ $\&$ fbid $=747030432005722$. Retrieved on March 12, 2016.

Bostanashvili D (2014) Freedom Square and Palace of Poetry. Tbilisi: Shota Bostanashvili Archive, https://flowersofstone.wordpress.com/english, accessed 17 April, 2016.

Bostanashvili S (1988) Unpublished explanatory note to the entry competition 'A Space for XXI Century Civilisation'. Tbilisi: Shota Bostanashvili Archive, 1988. http://gtu.ge/Arch/Poetics/poetics.html, accessed 4 November, 2015.

Bostanashvili S (1995) Unpublished leaflet of the exhibition marking the five years since the setting up of the studio-workshop Poetics of Architecture. Tbilisi: Shota Bostanashvili Archive (in Georgian).

Bostanashvili S (2001) Speech at the opening of the exhibition Architecture towards Architecture held on November 16, 2001. Video documentation of the exhibition. https://youtu.be/vTUiH56NsQQ (in Georgian), accessed 16 April, 2016.

Bostanashvili S (2003) Image, House, Name. Literaturuli Sakartvelo 50: 12 (in Georgian).

Bostanashvili S (2006) Sans reverence and sans Derrida. Sjani 7: 128-136 (in Georgian).

Bostanashvili S (2010a) Seafaring Pilgrims: (B) $\operatorname{art}(\mathrm{h})$ istic Performance. Semiotics 8: 335 (in Georgian).

Bostanashvili S (2010b) Poetics of Architecture. Tbilisi: Shota Bostanashvili Archive, http://gtu.ge/ Arch/Poetics/index.html, accessed 4 November, 2015.

Bostanashvili S (2012) Four Discourses. Tbilisi: Universali.

Bostanashvili S (2013) Paradigm of Ruins: Lecture delivered at the Conference of American Studies. Tbilisi: Tbilisi State University.
Bostanashvili S, Bostanashvili D (2006) Unpublished excerpt from the explanatory note to the competition entry exhibited at Karvasla Centre, October 2006. Tbilisi: Shota Bostanashvili Archive, (in Georgian).

Bostanashvili S, Bostanashvili D (2008) "The sign and the Built." Semiotics 4: 76-86 (in Georgian).

Bostanashvili S, Bostanashvili D (2009) Presenting concept of constructum. Semiotics 5: $117-$ 123 (in Georgian).

Bostanashvili S, Bostanashvili D (2012) Butza: Architect Victor Jorbenadze. Tbilisi: Ltd 'Universal'.

Camus A (1988) The Stranger. Translated by Matthew Ward. New York: Vintage International.

Chaubin F (2011) CCCP: Cosmic Communist Constructions Photographed. Köln: Taschen.

Derrida J (1995) On the Name. Translated by David Wood, John P. Leavey Jr, and Ian McLeod. Edited by Thomas Dutoit. Stanford: Stanford University Press.

Derrida J, Eisenman P (1997) Chora L Works, eds Jeffrey Kipnis and Thomas Lesser. New York: Monacelli Press.

Eco U (1968) La struttura assente. Introduzione alla ricera semiologica. Milan: Bompiani.

Eco U (1994) The Limits of Interpretation Advances in Semiotics. Bloomington. Indiana: Indiana University Press.

Eco U (2004) On Beauty: A History of a Western Idea. London: Martin Secker \& Warburg Ltd.

Epstein M (2004) On the Future of the Humanities. Moscow: Novoe Literaturnoe Obozrenie.

Foucault M (1994) Order of things: An archaeology of human sciences. New York: Vintage Books.

Heidegger M (1996) Being and Time. A Translation of Sein und Zeit. Translated by Joan Stambaugh. Albany, New York: SUNY Press.

Huizinga J (1949) Homo Ludens: A Study of the Play-Element in Culture. London: Routledge \& Kegan Paul [1944].

Jones A ed. (1966) The Jerusalem Bible. London: Darton: Longman and Todd.

Kalandadze E ed. (2015) Vakhtang Davitaia: Architecture, Painting, Graphics. Tbilisi: Magticom.

Lomidze G (2012) Introduction. In Four Discourses, by Shota Bostanashvili, 5-7. Tbilisi: Universali. 
Markov D F, Timofeev L I (1976) Socialist Realism. In Great Soviet Encyclopedia, eds Aleksander Mikhaǐlovich Prokhorov et al, vol. 24, 244-246. A translation of the third edition. New York, London: Collier Macmillan Publishers.

McCaffery S (2008) Parapoetics and the Architectural Leap. In A Time for the Humanities: Futurity and the Limits of Autonomy, eds James J. Bono, Tim Dean, Ewa P. Ziarek, 161-179. New York: Fordham University Press.
Svetlov I (1981) Bold idea, beautiful execution. Sabchota Khelovneba 4: 71-81 (in Georgian).

Terras V (1979) Phenomenological Observations on the Aesthetics of Socialist Realism. The Slavic and East European Journal 23.4: 445-457.

Woods L (2009) Architecture and Resistance. https://lebbeuswoods.wordpress.com/2009/05/09/arc hitecture-and-resistance/, accessed 17 April, 2016. 